\title{
Study of Surface Morphology and Topography of Pure Iron Machined by WEDM
}

\section{Katerina Mouralova ${ }^{1}$, Libor Benes ${ }^{2}$, Radim Zahradnicek ${ }^{1}$}

${ }^{1}$ Faculty of Mechanical Engineering, Brno University of Technology. Technicka 2896/2, 61669 Brno. Czech Republic. E-mail: mouralova@fme.vutbr.cz, zahradnicek@fme.vutbr.cz,

${ }^{2}$ Faculty of Production Technology and Management, J. E. Purkyne University in Usti nad Labem. Pasteurova 3334/7, 40001 Usti nad Labem. Czech Republic. E-mail: benes@fvtm.ujep.cz

Owing to its magnetic properties, pure iron is among materials investigated with a view to their use for improving existing memory media. Experimental equipment made of pure iron is prepared by using lithographic methods and magnetron sputtering, putting specific technological requirements on the input material. The non-conventional method of wire electrical discharge machining (WEDM) was used for the pure iron target in order to meet those requirements. The present study was devoted to the topology and morphology of the iron target machined by the electrical discharge method. Morphology was examined by scanning electron microscopy (SEM) as a method capable of visualising the contrast between the pure iron and the copper from the electrode material diffusing on the machined surface. Energy dispersive X-ray spectroscopy (EDX) was used to analyse the local chemical composition. The machined surface topography was examined based on its areal and profile parameters.

Keywords: WEDM, Electrical Discharge Machining, pure iron, morphology of surface, topography, chemical composion

\section{Acknowledgement}

This work was supported by the Ministry of Education, Youth and Sport of the Czech Republic, the program NPU1, project No. LO1207.

This Part of work was carried out with the support of core facilities of CEITEC - Central European Institute of Technology under CEITEC - open access project, ID number LM2011020, funded by Ministry of Education, Youth and Sports of the Czech Republic under the activity Projects of major infrastructures for research, development and innovations.

\section{References}

[1] ABBAS, N. M., SOLOMON, D. G., \& BAHARI, M. F. (2007). A review on current research trends in electrical discharge machining (EDM). In: International Journal of machine tools and Manufacture, pp. 1214-1228.

[2] HO, K. H., NEWMAN, S. T., RAHIMIFARD, S., \& ALLEN, R. D. (2004). State of the art in wire electrical discharge machining (WEDM). In: International Journal of Machine Tools and Manufacture, pp. 1247-1259.

[3] OSIČKA, K., FIŠEROVÁ, Z., OTOUPALÍK, J. (2015). Influence of cutting tool overhangs at machining of hardened steels. In: Manufacturing Technology, pp. 188-191.

[4] MOURALOVÁ, K.; BEDNÁŘ, J.; KOVÁŘ, J.; MACH, J. (2016). Evaluation of MRR after WEDM depending on the resulting surface. In: Manufacturing Technology, pp. 396-401.

[5] BLECHA, P.; PROSTREDNIK, D. (2011). Influence on the failure probability. Inteligent Manufacturing and Automation: Focus on Young Researches and Scientists, pp. 11-12.

[6] BLECHA, P. (2006). Integration of risk management into Meta- Quality Deployment method. In AEDS 2006 Workshop Proceedings. Plzeň: Západočeská univerzita v Plzni, pp. 23.

[7] MATOUSEK, R., BEDNAR, J. (2010). Grammatical evolution and STE criterion: Statistical properties of STE objective function.Lecture Notes in Electrical Engineering, vol 68, pp. 131-142.

[8] JAMESON, E. C. (2001). Electrical discharge machining. Society of Manufacturing Engineers. ISBN 0-87263521-X.

[9] ILJIAS, A., DUDONIS, J., BRUČAS, R., MEŠKAUSKAS, A. (2005). Thin ferro magnetic films deposition by facing target sputtering metod. Nonlinear Anal. Model. Control, vol. 10, pp. 57-64.

[10] JIANG, X. J., WHITEHOUSE, D. J. (2012). Technological shifts in surface metrology. CIRP Annals-Manufacturing Technology, 61(2), pp. 815-836. 
[11] WAIKAR, R. A., GUO, Y. B. (2008). A comprehensive characterization of 3D surface topography induced by hard turning versus grinding. Journal of materials processing technology, 197(1), pp.189-199.

[12] HUANG, J. T., LIAO, Y. S. (2003). Optimization of machining parameters of wire-EDM based on grey relational and statistical analyses. International Journal of Production Research, 41(8), pp. 1707-1720.

[13] HUANG, Y., MING, W., GUO, J., ZHANG, Z., LIU, G., LI, M., ZHANG, G. (2013). Optimization of cutting conditions of YG15 on rough and finish cutting in WEDM based on statistical analyses. The International Journal of Advanced Manufacturing Technology, 69(5-8), pp. 993-1008.

[14] MCGEOUGH, J. A. (1988). Advanced methods of machining. Springer Science \& Business Media.ISBN 9780412319709.

[15] NEWTON, T. R., MELKOTE, S. N., WATKINS, T. R., TREJO, R. M., REISTER, L. (2009). Investigation of the effect of process parameters on the formation and characteristics of recast layer in wire-EDM of Inconel 718. Materials Science and Engineering: A, 513, pp. 208-215.

\section{Paper number: M2016194}

Copyright $\odot$ 2016. Published by Manufacturing Technology. All rights reserved. 